\title{
Attitudes of nursing students towards substance users and perceptions about religious/spiritual care*
}

\author{
Atitudes de estudantes de enfermagem frente ao usuário de substâncias \\ e percepções sobre o cuidado religioso/espiritual \\ Actitudes de estudiantes de enfermería ante el adicto a sustancias \\ y percepciones acerca del cuidado religioso/espiritual
}

\begin{abstract}
Angelica Martins de Souza Gonçalves ${ }^{1}$, Manoel Antônio dos Santos ${ }^{2}$, Rosa Maria Jacinto Volpato ${ }^{1}$, Erikson Felipe Furtado $^{3}$, Teresa Maria Mendes Diniz de Andrade Barroso ${ }^{4}$, Sandra Cristina Pillon ${ }^{5}$
\end{abstract}

How to cite this article:

Gonçalves AMS, Santos MA, Volpato RMJ, Furtado EF, Barroso TMMDA, Pillon SC. Attitudes of nursing students towards substance users and perceptions about religious/spiritual care. Rev Esc Enferm USP. 2018;52:e03425. DOI: http://dx.doi.org/10.1590/S1980-220X2017027903425

\footnotetext{
* Extracted from the thesis: "Atitudes dos estudantes de Enfermagem em relação ao usuário de substâncias psicoativas e a ênfase nos aspectos religiosos e espirituais do cuidado", Escola de Enfermagem de Ribeirão Preto, Universidade de São Paulo, 2013.

${ }^{1}$ Universidade Federal de São Carlos, São Carlos, SP, Brazil.

${ }^{2}$ Universidade de São Paulo, Faculdade de Filosofia, Ciências e Letras de Ribeirão Preto, Ribeirão Preto, SP, Brazil.

${ }^{3}$ Universidade de São Paulo, Faculdade de Medicina de Ribeirão Preto, Ribeirão Preto, SP, Brazil.

${ }^{4}$ Escola Superior de Enfermagem de Coimbra, Coimbra, Portugal.

${ }^{5}$ Universidade de São Paulo, Escola de Enfermagem de Ribeirão Preto, Ribeirão Preto, SP, Brazil.
}

\begin{abstract}
Objective: To evaluate the impact of an educational intervention on the attitudes of Nursing students towards users of psychoactive substances (excluding alcohol and tobacco) and their perceptions about the religious and spiritual care offered within the health services. Method: Quasi-experimental study. We applied a questionnaire before and one month after an intervention about the comprehensive care of substance users, containing: sociodemographic information, knowledge, the Treatment Spirituality/ Religiosity Scale, and the Drug and Drug Problems Perceptions Questionnaire. For the analyses, we employed the paired Student's t-test and Pearson's Coefficient. Results: 62 students participated in this study. After the intervention, there was improvement in the students' attitudes towards the substance users, but not regarding the perception they already had about the importance of offering religious and spiritual care within the services. Conclusion: We verified the effectiveness of the educational intervention on the improvement of attitudes concerning the care of substance users, yet we point out that the students did not show changes in their perception about the inclusion of the religious and spiritual aspects in the care dedicated to this population.
\end{abstract}

\section{DESCRIPTORS}

Students, Nursing; Health Attitudes and Practice; Knowledge; Substance-Related Disorders; Spirituality. 


\section{INTRODUCTION}

The educational process of Nursing is ideally developed within an articulated and complex network in which theoretical and practical contents are inserted, as well as interactions between professors and students, and between students and the users of the health services, which arise in the several scenarios of professional training ${ }^{(1)}$. An aspect inherent to the quality evaluation of this training refers to the students' attitudinal elements, and this knowledge may be useful for evaluating human conduct. Traditionally, attitude may be conceptualized as classes of evaluation responses relative to an object, person, or group, constituted by affective, cognitive, and behavioral components. It is a state of mental readiness susceptible to change, given that these evaluative responses may be considered learned rather than innate predispositions ${ }^{(2)}$.

The health area, by appropriating the construct, has been benefiting from the study of the "attitudes" under different theoretical perspectives and methodological strategies, with studies that have been developed with the purpose of investigating the relationship between student and professional attitudes and the diverse actions that are part of the repertoire of Nursing practice in this investigation field ${ }^{(3-4)}$.

It is known that, among other factors, attitudes may be influenced by the level of knowledge one has regarding a given subject ${ }^{(2,4)}$. In this sense, studies highlight that Nursing professionals are still receiving little or no information during their academic education period, or their training after graduation, on issues concerning the use of alcohol and/or other drugs ${ }^{(5-6)}$. Nevertheless, they routinely provide care for people that use these substances in their diverse consumption patterns and the health network's various levels of care ${ }^{(5)}$. The knowledge gap also extends to religious and spiritual assistance ${ }^{(7)}$, which has been considered by the literature as fundamental in the scope of preventive actions and the rehabilitation of the user of alcohol and/or other drugs.

The number of studies about the relationship between religiosity/spirituality and health has increased in the last decades in the Brazilian and international scenarios ${ }^{(8)}$. Such constructs are intimately related to the notion of belief. Belief may be defined as the psychological state in which a person has a formed premise or opinion/conviction regarding a given object or fact - for example, a system of beliefs concerning a specific religion or, more broadly, spirituality. It is relevant to make a conceptual distinction between the terms "spirituality" and "religiosity". The first refers to what gives people meaning and a purpose in life, encompassing the relationship established with the dimension of the sacred, but not necessarily related to a given religion. In turn, religiosity is conceived as a sectary practice which is part of an organized system of beliefs, practices, and traditions of a religious denomination, created to facilitate the approximation to the sacred or transcendent $t^{(9)}$. In the exercise of care, however, these two constructs may be worked and perceived jointly in the different points of the network where the Nursing professional acts ${ }^{(10)}$.
Spiritual care is part of the Nursing process and requires the development of abilities and competencies in the interpersonal process, which includes attention and respect for the patient's religious beliefs. It assumes an evaluation of the spiritual well-being, related diagnostics, interventions, and systemic evaluation of the results ${ }^{(11)}$.

The way we must welcome and assist the religious and spiritual aspects is not consensual, yet it has the purpose of aiding the individual in solving personal conflicts, promote their acceptance in the face of an adverse condition, and appease their level of suffering ${ }^{(7,12)}$. Therefore, the care in this field must be planned using interpersonal tools such as communication, listening, acceptance, strengthening of the trust bond, and mature emotional involvement, which may be thought in the light of a theoretical framework ${ }^{(12)}$.

The investigation of the relationships between the attitudes and perceptions about religious and spiritual care offered to the users of psychoactive substances, in the perspective of those who are in professional training, may be a useful and sensitive resource to identify eventual discrepancies that might exist between theory and practice of the comprehensive care destined to a specific group of users of the services. This is because, in theory, the more adequate the attitudes in the face of a given object are, the apter the individual will feel to freely manifest their perceptions and opinions since these variables are influenced by the level of knowledge one has regarding a given subject. In this regard, we outlined the following research question: "if there is change in the attitudes of the Nursing students in relation to users of alcohol and/or drugs due to the raising of their level of knowledge about comprehensive care in the field, will the perception they have about the religious and spiritual care provided in the services also be altered?"

Little attention has been given to the way the attitudes towards users of psychoactive substances may influence the religious and spiritual care offered, especially to drug users. Furthermore, it is not clear in the scientific literature how the acquisition of new knowledge of the area synchronously influences such variables.

Given the exposed, this study had the objective of evaluating the impact of the educational intervention on the relationships between the attitudes of Nursing students towards users of psychoactive substances (excluding alcohol and tobacco) and their perceptions about the religious and spiritual care offered within the health services.

\section{METHOD}

\section{StUdY TYPE}

This is a quasi-experimental study with pre- and posttest groups $^{(13)}$. We applied a pre-test evaluation with the students about their attitudes towards working with users of psychoactive substances and their perceptions about the religious/spiritual care of such people in the health services (dependent variables). Next, we elaborated and applied an educational intervention about the comprehensive care for the user of alcohol and drugs (independent variable) and, 
after a month, performed a new assessment of the same variables. The purpose of this intervention was improving the level of knowledge about the comprehensive care of psychoactive substance users, capacitating the participants for the understanding of the phenomenon of substance use as a daily and recurrent situation in Nursing assistance, that is, we sought to investigate possible differences in the attitudes and perceptions provided by the knowledge acquired by the student during the proposed intervention. To instrumentalize the student, we offered tools that could be applied in work in different contexts, based on Joyce Travelbee's Theory, devised as a resource to treat the interpersonal aspects that permeate religious and spiritual care.

We resorted to the traditional teaching method and used dialogued expository lessons to present the program content, which was developed over sixteen hours and encompassed the following materials: (1) epidemiology and classification of the primary psychoactive substances used in Brazil; (2) tracking and brief interventions starting with ASSIST (Alcohol, Smoking, and Substance Involvement Screening Test); the ASSIST is a test that enables the tracking of the use of alcohol and other drugs that has been useful in Nursing practice ${ }^{(14)}$; (3) the user of psychoactive substances assisted by using the diverse equipment of the health network; and (4) substance user care to the religious and spiritual dimension, stemming from precepts of person-toperson relationships ${ }^{(12)}$.

\section{Data COllection}

We collected the data from June to October of 2012. We invited to participate in the study 452 Nursing students from two higher education institutions (one public, where the educational intervention occurred, and the other private) from a municipality in the state of Mato Grosso, Brazil. From this universe, we recruited 62 students who met the following inclusion criteria: being a regularly enrolled student in any semester of the Bachelor of Nursing course; being at least eighteen years old; having already provided some assistance in which it was necessary to approach the issue of psychoactive substance use; and participating in all classes of an educational intervention program about the comprehensive care of users of psychoactive substances. The exclusion criteria were: not answering the research instrument completely and having been exposed to some other type of training to provide care for users of psychoactive substances before the second application of the research instrument.

\section{INSTRUMENTS}

The research instruments consisted of (1) sociodemographic information form (age, gender, occupation, religion, religious practice, and graduation year); (2) information about overall aspects of the provision of care for users of psychoactive substances: signs and symptoms of abuse and dependency; approach in the service, counseling, and treatment, instruments of tracking and spiritual care, with options for much, little, or no information; (3) scale about attitudes towards working with drug users (except alcohol and tobacco), the Brazilian version of the Drug and Drug Problems Perceptions Questionnaire (DDPPQ-br) ${ }^{(15)}$; and (4) the Brazilian version of the scale of perception about the religious and spiritual care within the services, entitled Treatment Spirituality/Religiosity Scale (Brazilian version: TSRS-br) ${ }^{(10)}$. Both DDPPQ-br and TSRS-br were validated for Brazil in 2012 in the context of the same thesis ${ }^{(15)}$.

The DDPPQ measures the students' attitudes towards working with users of psychoactive substances. The version validated for Brazil (DDPPQ-br) presented a Cronbach's alpha of 0.85 , a value close to that of its original version $(0.87)^{(16)}$. The items of this questionnaire evaluate the safety in working with people that use drugs (except alcohol and tobacco), adequate knowledge to exercise the function, how much the individuals consider themselves apt and endowed of appropriate knowledge to handle their patients' problems, motivation, expectations, professional satisfaction, and the professional's self-esteem to work with the referred public ${ }^{(16)}$. It is an instrument that may be self-applied, composed of twenty items. The response alternatives are of the Likert type and vary from zero ( 0 - totally agree) to seven ( 7 - totally disagree). In this scale, the higher the summation of the score, the worse the manifested attitudes are ${ }^{(16)}$.

The TSRS-br assesses the perception of the students about the inclusion of spirituality/religiosity aspects in the assistance of users of psychoactive substances. This instrument was validated for the Brazilian context ${ }^{(10)}$. It is constituted by ten items that evaluate how much religious and spiritual aspects are valued in the different scopes of assistance to users of psychoactive substances, be them formal points of the health network or not. Such items include seven assertions related to the actions of the service professionals towards religious and spiritual assistance and three about individual actions of users of the service concerning the theme. The responses are dichotomic, "true" or "false", and, in their readings, the affirmatives regarding the inclusion of religiosity/spirituality in the care are coded as being worth one point, while the negatives are worth zero. Then, they are summed ${ }^{(10,17)}$.

\section{DATA ANALYSIS AND TREATMENT}

We elaborated a database with double typing and posterior validation using Microsoft Excel 2000. Then, we transferred the data to SPSS version 19 (license number 10250887) for the analyses. Regarding the descriptive analysis, for the sociodemographic variables, we calculated central tendency measures (means and medians) and dispersion measures (minimums and maximums, quartiles, and standard-deviations). We computed frequencies to measure the knowledge about the care of psychoactive substance users. To compare the scores of the DDPPQ-br and TSRS-br scales obtained before and after the intervention, we applied the paired Student's t-test. To verify the correlation between the total scores of the two instruments, we calculated Pearson's Correlation Coefficient. The confidence interval (CI) adopted was of $95 \%$. 


\section{ETHICAL ASPECTS}

Abiding by Resolution no. 466/2012 of the Brazilian National Health Council, this study was approved by the Research Ethics Committee of the university institution to which the researcher is associated, under opinion no. 45678/2012. The participants signed Informed Consent Form.

\section{RESULTS}

The average age of the sample was of 23 years $(\mathrm{SD}=4.83)$, varying from 19 to 39 years. The participants were predominantly women $(50,80.6 \%)$ and single $(39,62.9 \%)$. Regarding the work questions, the majority reported not having a work bond; among those who worked, three (4.8\%) were at the job for at most one year, seven (11.3\%) for over one and less than three years, and four (6.4\%) were at the same job for more than three years.

Regarding the health services in which the students most experienced practical dealing with psychoactive substance users in the healthcare network, both in the condition of health professionals and as interns, forty (64.5\%) referred the Basic Healthcare Units, eighteen (29\%) reported the hospitals, and four (6.4\%), the mental health services.
Concerning religion, most students declared themselves Catholic, followed by the Evangelicals, and claimed to be practitioners of their religious faiths (Table 1).

Table 1 - Sociodemographic information about the Nursing students who participated in the study - Mato Grosso, Brazil, 2012.

\begin{tabular}{llcc}
\hline Sociodemographic characteristics & N & $\%$ \\
\hline Gender & Women & 50 & 80.6 \\
& Men & 12 & 19.4 \\
\hline Occupation & Does not work, just studies & 48 & 77.4 \\
& Already works in the health area & 6 & 8.1 \\
& Works outside the health area & 8 & 12.9 \\
\hline Religion & Catholic & 32 & 51.6 \\
& Evangelical & 24 & 38.7 \\
& Spiritist & 3 & 4.8 \\
& Does not have one, but believes in God & 2 & 3.2 \\
& Atheist & 1 & 1.6 \\
\hline Religious & Yes & 46 & 74.2 \\
practice & No & 13 & 20.9 \\
& Does not apply & 3 & 4.8 \\
\hline
\end{tabular}

Note: $(\mathrm{N}=62)$.

Figure 1 shows the information about the recruitment of the participants, adapted from CONSORT $2010^{(18)}$.

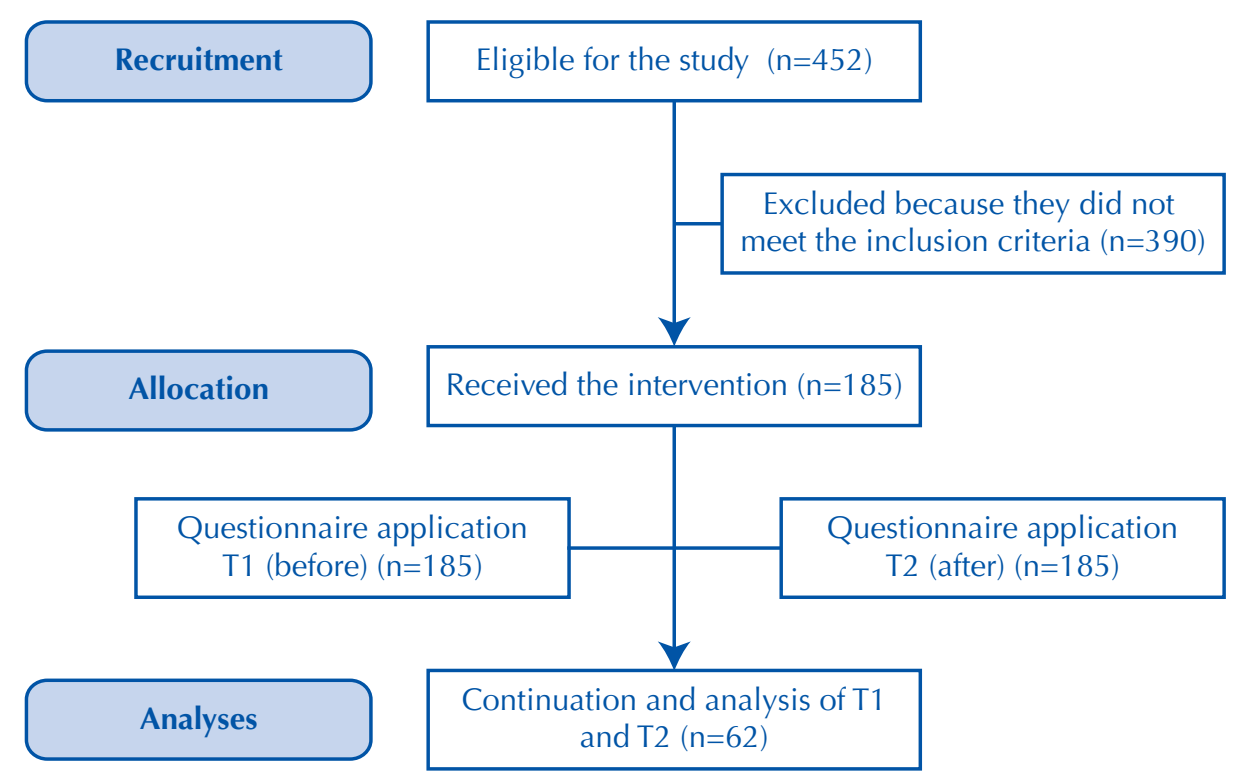

Figure 1 - Flowchart of the recruiting of participants.

We observed improvement in the level of information about the care offered to the users of psychoactive substances, including the religious and spiritual aspects, as shown in Table 2. There was a statistically significant difference among the students'attitudes towards working with psychoactive substance users before and after receiving an educational intervention (Table 3). The same did not occur regarding the students' perception about the religious and spiritual care offered within the health services that assist users of psychoactive substances.
Likewise, we did not find a correlation between the DDPPQ-br and TSRS-br scores neither before $(r=0.07$, $\mathrm{p}$-value $=0.579)$ nor after the educational intervention $(r=0.000, p-v a l u e=0.978)$, which means that, despite the improvement in their attitudes and levels of knowledge about the care that includes the religious and spiritual aspects, the participants did not observe a valuation of this care in the assistance provided to psychoactive substance users within the health services. 
Table 2 - Information about the comprehensive care of the users of psychoactive substances (PAS), according to Nursing students before and after the educational intervention - Mato Grosso, Brazil, 2012.

\begin{tabular}{|c|c|c|c|c|c|c|c|c|c|c|c|c|}
\hline & \multicolumn{6}{|c|}{ Before (T1) } & \multicolumn{6}{|c|}{ After (T2) } \\
\hline & \multicolumn{2}{|c|}{ NI } & \multicolumn{2}{|c|}{ PI } & \multicolumn{2}{|c|}{ MI } & \multicolumn{2}{|c|}{ NI } & \multicolumn{2}{|c|}{ PI } & \multicolumn{2}{|c|}{ MI } \\
\hline & $\mathbf{N}$ & $\%$ & $\mathbf{N}$ & $\%$ & $\mathbf{N}$ & $\%$ & $\mathbf{N}$ & $\%$ & $\mathbf{N}$ & $\%$ & $\mathbf{N}$ & $\%$ \\
\hline Signs and symptoms of use, abuse, and dependence of PAS & 3 & 4.8 & 50 & 80.6 & 9 & 14.5 & - & - & 22 & 35.5 & 40 & 64.5 \\
\hline Approach about the use of PAS in the service & 20 & 32.2 & 41 & 66.1 & 1 & 1.6 & 3 & 4.8 & 26 & 41.9 & 33 & 53.2 \\
\hline Counseling and treatment & 13 & 21 & 43 & 69 & 6 & 9.7 & - & - & 26 & 41.9 & 35 & 56.5 \\
\hline Tracking instruments & 24 & 38.7 & 35 & 56.5 & 3 & 4.8 & - & - & 22 & 35.5 & 40 & 64.6 \\
\hline Spiritual care of the user of PAS & 3 & 4.8 & 57 & 91.9 & 2 & 3.2 & - & - & 2 & 3.2 & 60 & 96.7 \\
\hline
\end{tabular}

*NI - No information; LI - Little information; MI - Much information

Note: $(\mathrm{N}=62)$.

Table 3 - Comparison of the scores for the DDPPQ-br and TSRSbr scales evaluated before (T1) and after (T2) the educational intervention - Mato Grosso, Brazil, 2012.

\begin{tabular}{lccccccc}
\hline Scales & \multicolumn{1}{c}{ Time } & Minimum Maximum Median & Mean & SD & $\mathbf{P}$ \\
\hline \multirow{2}{*}{ DDPPQ-br } & 1 & 47 & 118 & 70.5 & 74.0 & 13.8 & \\
& 2 & 28 & 114 & 63.5 & 62.8 & 16.9 & \\
\hline \multirow{2}{*}{ TSRS-br } & 1 & 0 & 9.0 & 4.0 & 3.9 & 2.6 & \\
& 2 & 0 & 10.0 & 5.0 & 4.5 & 3.2 & 0.0835 \\
&
\end{tabular}

*Paired Student's t-test $\mathrm{p}<0.05$

Note: $(\mathrm{N}=62)$

\section{DISCUSSION}

Regarding the research question, the results showed that the improvement of the attitudes towards working with psychoactive substance users does not alter the Nursing students' perception about their individual action and also of the health professionals on the valuation of the offer of religious and spiritual care within the health services. This occurs despite the improvement of the level of knowledge about comprehensive assistance, which reinforces the idea of disarticulation between theory and practice. This may be related to an issue that transcends the subjective dimension, remitting to a broader and quite objective condition which is the stigma that accompanies the person identified as a drug user. One hypothesis that can be raised based on the literature is that, because it is a socially recriminated and highly stigmatized behavior $^{(19)}$, the consequences of this negative perception have a reflection on the services and in the way the individuals are assisted. If they encounter a discriminatory service, they do not establish a bond of trust with the professionals and, consequently, do not adhere to the treatment; thus, their health situations might aggravate with the installation of possible clinical complications of diverse natures ${ }^{(20)}$.

Although the condition of dependency is evident in some cases, it is worth emphasizing that most people who seek health services may be users of some licit or illicit substance, with different consumption patterns, but this consumption may often be undervalued and even neglected or not investigated, including in the case of those users who present some mental health problem associated to drug use, who are prone to be frequent users of emergency units ${ }^{(21)}$.

This study's findings suggest that the self-perception of higher information levels is related to the improvement of the Nursing students' attitudes towards working with psychoactive substance users $^{(2,22)}$. If, on the one hand, this data may be considered positive, on the other hand, before the educational intervention was offered, the insufficiency of a minimum primary education that enables them to provide care became evident. The fact that the majority of the sample was constituted by students who had already completed half of the Nursing course or were finalizing it (third and fourth years) demonstrates a significant gap in the academic education of nurses, thus corroborating the findings of other studies ${ }^{(5-6)}$.

The reinforcement of positive attitudes towards users of psychoactive substances is related to several factors, such as being prepared to work with dependants, having the backing of a considerable workload of studies on the subject, and having a high education level ${ }^{(23)}$. That is to say that incrementing positive attitudes requires training specific to the area which brings evidence of good results for the clinical practice ${ }^{(23-24)}$. The same reasoning may be applied to religious and spiritual care, seeing that studies mention that, among the challenges to be overcome so that Nursing students and professionals appreciate, in their provision of care, the subjective aspects of the human being (this extends to users of alcohol and other drugs), there are the lack of knowledge and proper training, the biologist view of care, and the influence of beliefs based on common sense, other than personal limitations such as religious questionings, conceptions about the meaning of life, and internal conflicts ${ }^{(22,25-26)}$.

It is known that there are differences in the understanding of nurses about what religious and spiritual care is and how it should be provided. However, the modus operandi is always based on light technologies such as listening, respect of the beliefs, and communication ${ }^{(27)}$. Recognized barriers in this field include the fear of imposing personal viewpoints and, again, the professional's perception of unpreparedness ${ }^{(28)}$. It is concerning to note that these fundamental elements to the practice of Nursing, and not only of Mental Health, are not being perceived as regular practices by the students in the routine of providing care for substance users.

Higher-level education curricula usually encompass some courses that address interpersonal aspects ${ }^{(29-30)}$ and dimensions of religious and spiritual care ${ }^{(7)}$, glimpsing a transformation towards an education which is more humanized and less anchored on contents centered around 
the biomedical model ${ }^{(30)}$. However, this study's findings, in agreement with other research efforts, point to a need to reinforce attitudinal aspects of the Nursing training so to favor the overcoming of daily professional challenges ${ }^{(1)}$.

Such challenges permeate the knot identified in this study: even with the improvement of the knowledge about the comprehensive care and of the attitudes towards working with drug users, after applying the educational intervention, the religious and spiritual care, which is admittedly essential in facing the problems stemming from substance use $\mathrm{e}^{(25)}$, is seen as something neglected in the services according to the perception of future nurses. It is worth noting that the learning environments are models of the students' attention and attitude forming ${ }^{(31)}$.

A possible path to overcome this Gordian knot would be to avoid reproducing the work process based on the positivist model, which separates the individual from their subjectivity, a model that prevails in Nursing education. The change requires more investment in training that overcomes the predominance of technical knowledge over the care and values more the aspects that go beyond the physical body, ensuring the minimum time required to really put comprehensive care into practice ${ }^{(31)}$. In the case of the assistance to psychoactive substance users, this may be fundamental since the motivation for changing their behavior and disposition for adhering to treatment are related to the relational practices, including the religious and spiritual dimensions in the care ${ }^{(26)}$.

This study's limitations are inherent to the methodological design adopted. Although it is useful for evaluating programs or pilot projects, especially those in which some previous knowledge already signals how the dependent variable behaves, there is the possibility that the intervening factors, other than the applied intervention, may interfere with the results obtained ${ }^{(13)}$. Furthermore, there are diver ${ }^{-}$ gences among the frameworks that base the theory from person to person (used in the educational intervention) and the theoretical build of the instrument that measured the perception about the religious and spiritual aspects (TSRS-br). Even so, the first was used as a Nursing resource to evidence how, in practice, some elements may enable religious and spiritual care. Also it would have been ideal that students had returned to the professional practice fields afterwards to a new observation, which was not possible in this study's context.

\section{CONCLUSION}

We verified the effectiveness of the educational intervention in the improvement of the attitudes towards providing care for substance users. However, we did not find evidence that the increase in the level of knowledge about this theme simultaneously generates changes in the Nursing students' perceptions about the religious and spiritual care provided within the services. This may be related to gaps in the professionals' academic education which may result in the disarticulation between theory and practice. The valuation of aspects in the Nursing training which are not limited to technical knowledge but emphasize the potentials of light technologies as primordial resources of comprehensive care might have positive implications for the assistance to psychoactive substance users.

\section{RESUMO}

Objetivo: Avaliar o impacto de uma intervenção educativa sobre as atitudes de estudantes de Enfermagem frente ao usuário de substâncias psicoativas (excluindo-se álcool e tabaco) e as percepções sobre o cuidado religioso e espiritual oferecido nos serviços de saúde. Método: estudo quase-experimental. Aplicou-se um questionário antes e 1 mês após a realização de uma intervenção sobre cuidado integral ao usuário de substâncias, contendo: informações sociodemográficas, conhecimentos, Treatment Spirituality/Religiosity Scale e o Drug and Drug Problems Perceptions Questionnaire. Para as análises, utilizou-se do teste t de Student pareado e o coeficiente de Pearson. Resultados: Participaram 62 estudantes. Depois da aplicação da intervenção houve melhora das atitudes dos estudantes diante do usuário de substâncias, mas não em relação à percepção que já tinham sobre a importância da oferta de cuidado religioso e espiritual nos serviços. Conclusão: Verificou-se efetividade da intervenção educativa na melhora das atitudes em relação ao cuidado do usuário de substâncias, mas se alerta ao fato de que os estudantes não apresentaram mudanças em sua percepção sobre a inclusão dos aspectos religiosos e espirituais no cuidado dedicado a essa população.

\section{DESCRITORES}

Estudantes de Enfermagem; Atitudes e Práticas em Saúde; Conhecimentos; Transtornos Relacionados ao Uso de Substâncias; Espiritualidade.

\section{RESUMEN}

Objetivo: Evaluar el impacto de una intervención educativa acerca de las actitudes de estudiantes de Enfermería ante el usuario de sustancias psicoactivas (excluyéndose el alcohol y el tabaco) y las percepciones acerca del cuidado religioso y espiritual ofrecido en los servicios sanitarios. Método: estudio cuasi-experimental. Se aplicó un cuestionario antes y un mes después de la realización de una intervención acerca del cuidado integral con el adicto a sustancias, conteniendo: informaciones sociodemográficas, conocimientos, Treatment Spirituality/Religiosity Scale y el Drug Problems Perceptions Questionnaire. Para los análisis, se utilizó la prueba de t de Student pareada y el coeficiente de Pearson. Resultados: Participaron 62 estudiantes. Después de la aplicación de la intervención hubo mejora de las actitudes de los estudiantes ante el adicto a sustancias, pero no con relación a la percepción que ya tenían sobre la importancia de la oferta de cuidado religioso y espiritual en los servicios. Conclusión: Se verificó la efectividad de la intervención educativa en la mejora de las actitudes con relación al cuidado del adicto a sustancias, pero se llama la atención al hecho de que los estudiantes no presentaron cambios en su percepción sobre la inclusión de los aspectos religiosos y espirituales en el cuidado dedicado a dicha población.

\section{DESCRIPTORES}

Estudiantes de Enfermería; Actitudes y Práctica en Salud; Conocimientos; Trastornos Relacionados con Sustancias; Espiritualidad. 


\section{REFERENCES}

1. Messas JT, Leonello VM, Fernandes MFP, Gonçalves GCC, Bucchi SM, Mira VL. The educational environment of the undergraduate nursing course from the student perspective. Rev Esc Enferm USP. 2015;49(n.spe2):106-14. DOI: 10.1590/S0080-623420150000800015

2. Harling MR, Turner W. Student nurses' attitudes to illicit drugs: a grounded theory study. Nurs Educ Today. 2012;32(3):235-40. DOI: 10.1016/j.nedt.2011.05.002.

3. Evers C, Ploeg J, Kaasalainen S. Case study of the attitudes and values of nursing students toward caring for older adults. J Nurs Educ. 2011;50(7):404-9. DOI: 10.3928/01484834-20110429-03

4. Rajkumar E, Julious S, Salome A, Jennifer G, John AS, Kannan L, et al. Effects of environment and education on knowledge and attitude of nursing students towards leprosy. Indian J Lepr. 2011;83(1):37-43.

5. Varela DSS, Sales IMM, Silva FMD, Monteiro CFS. Health network assisting users of alcohol, crack, and other drugs. Esc Anna Nery. 2016;20(2):296-302. DOI: 10.5935/1414-8145.20160040

6. Vargas D, Oliveira MAF, Duarte FAB. Psychosocial Care Center for Alcohol and Drugs (CAPS-ad): nursing insertion and practices in São Paulo City, Brazil. Rev Latino Am Enfermagem. 2011;19(1):115-22. DOI: 10.1590/S0104-11692011000100016.

7. Tomasso CS, Beltrame IL, Lucchetti G. Knowledge and attitudes of nursing professors and students concerning the interface between spirituality, religiosity and health. Rev Latino Am Enfermagem. 2011;19(5):1205-13. DOI: 10.1590/S0104-11692011000500019

8. Koenig HG. Spirituality in patient care: why, how, when and what. 3rd ed Philadelphia: Templeton Foundation Press; 2013.

9. Piacentine LB. Spirituality, religiosity, depression, anxiety, and drug-use consequences during methadone maintenance therapy. West J Nurs Res.2013;35(6):795-814. DOI: 10.1177/0193945913479452.

10. Gonçalves AMS, Santos MA, Chaves ECL, Pillon SC. Transcultural adaptation and validation of the Brazilian version of Treatment Spirituality/ Religiosity Scale. Rev Bras Enferm. 2016;69(2):235-41. DOI: 10.1590/0034-7167.2016690205i

11. Caldeira S, Carvalho EC, Vieira M. Between spiritual well being and spiritual distress: possible related factors in elderly patients with cancer. Rev Latino Am Enfermagem. 2014;22(1):28-34. DOI: 10.1590/0104-1169.3073.2382

12. Chandramohan S, Bhagwan R. Utilization of spirituality and spiritual care in nursing practice in public hospitals in KwaZulu-Natal, South Africa. Religions. 2016;7(3):23. DOI: 10.3390/rel7030023

13. Shadish WR, Cook TD, Campbell DT. Experimental and quasi-experimental designs for generalized causal inference. Boston: Houghton Mifflin; 2002

14. Gonçalves AMS Ferreira PS, Abreu AMM, Pillon SC, Jezus SV. Estratégias de rastreamento e intervenções breves como possibilidades para a prática preventiva do enfermeiro. Rev Eletr Enf. 2011;13(2):355- 60. DOI: http://dx.doi.org/10.5216/ree.v13i2.10502

15. Gonçalves AMS. Atitudes dos estudantes de enfermagem em relação ao usuário de substâncias psicoativas e a ênfase nos aspectos religiosos e espirituais do cuidado [tese doutorado]. Ribeirão Preto: Universidade de São Paulo, Escola de Enfermagem de Ribeirão Preto; 2013.

16. Watson H, Maclaren W, Kerr S. Staff attitudes towards working with drug users: development of the Drug Problems Perceptions Questionnaire. Addiction. 2007;102(2):206-15. DOI: 10.1111/j.1360-0443.2006.01686.x.

17. Lillis J, Gifford E, Humphreys K, Moos R. Assessing spirituality/religiosity in the treatment environment: the Treatment Spirituality/Religiosity Scale. J Subst Abuse Treat. 2008;35(4):427-33. DOI: 10.1016/j.jsat.2008.02.002.

18. Schulz KF, Altman DG, Moher D. CONSORT 2010 statement: updated guidelines for reporting parallel group randomised trials. BMC Med. 2010;8(1):18. DOI: 10.1016/j.ijsu.2011.09.004

19. Toledo L, Góngora A, PM Bastos FI. À margem: uso de crack, desvio, criminalização e exclusão social: uma revisão narrativa. Ciên Saúde Coletiva. 2017;22(1):31-42. DOI: 10.1590/1413-81232017221.02852016.

20. Scioli G, Carmona-Torres J, Paniccia A, Battista A, Cavicchia I, Bishar RM. A study on the perception of the stigma related to drug use in a sample of Italians and Belgians. Psy Soc Educ. 2015;7(1):85-95. DOI: 10.25115/psye.v7i1.536.

21. Chan YF, Lu SE, Howe B, Tieben H, Hoeft T, Unützer J. Screening and follow-up monitoring for substance use in primary care: an exploration of rural-urban variations. J Gen Intern Med. 2016;31(2):215-22. DOI: 10.1007/s11606-015-3488-y.

22. Wylie LWJ. Assessing user perceptions of staff training requirements in the substance use workforce: a review of the literature. Drug-Educ Prev Polic. 2010;17(5):618-31. DOI: 10.3109/09687631003705538.

23. Soares J, Vargas D, Formigoni MLOS. Atitudes e conhecimentos de enfermeiros frente ao álcool e problemas associados: impacto de uma intervenção educativa. Rev Esc Enferm USP. 2013;47(5):1172-79. DOI: 10.1590/S0080-623420130000500023

24. Rosa NRP, Abreu ÂMM, Barroso TMMDA. Effect of brief interventions in reducing hazardous alcohol consumption in users receiving methadone treatment. Rev Enf Ref. 2015;4(6):27-34. DOI: 10.12707/RIV14082

25. Souza ICW, Ronzani TM. Alcohol and drugs in primary care: evaluating strategies for training. Psicol Estud. 2012;17(2):237-46. DOI: 10.1590/S1413-73722012000200007.

26. Oliveira ALCB, Feitosa CDA, Santos AG, Lima LAA, Fernandes MA, Monteiro CFS. Spirituality and religiosity in the context of drug abuse. Rev Rene. 2017;18(2):283-90. DOI: 10.15253/rev\%20rene.v18i2.19274.

27. Nascimento LC, Oliveira FCSD, Moreno MF, Silva FMD. Spiritual care: an essential component of the nurse practice in pediatric oncology. Acta Paul Enferm. 2010;23(3):437-40. DOI: 10.1590/S0103-21002010000300021.

28. Espinha DCM, de Camargo SM, Silva SPZ, Pavelqueires S, Lucchetti G. Opinião dos estudantes de enfermagem sobre saúde, espiritualidade e religiosidade. Rev Gaúcha Enferm. 2013;34(4):98-106.

29. Esperidião E, Silva NS, Caixeta CC, Rodrigues J. The psychiatric nursing, ABEn and the Scientific Department of Psychiatric and Mental Health Nursing: progress and challenges. Rev Bras Enferm. 2013;66(n.esp):171-6. DOI: 10.1590/S0034-71672013000700022. 
30. Silén M, Johansson L. Aims and theoretical frameworks in nursing students' Bachelor's theses in Sweden: a descriptive study. Nurse Educ Today. 2016;37:91-6. DOI: 10.1016/j.nedt.2015.11.020.

31. Machado MLP, Oliveira DLLCD, Manica ST. Extended nursing consultation: education possibilities for the practice of integrality in health. Rev Gaúcha Enferm. 2013;34(4):53-60. DOI: 10.1590/S1983-14472013000400007.

\begin{tabular}{|l|l}
\hline (cc) BY This is an open-access article distributed under the terms of the Creative Commons Attribution License. \\
\hline
\end{tabular} 